\title{
A tribute to
}

A. W. DOW N I E

Allan Watt Downie had his 81st birthday on 5 September 1982 . He will hardly have noticed it, for A.W.D. is a prime example of how wrong it can be to count age by the passage of time. That Sunday morning actually found him on the Royal Birkdale golf course, slightly irritated at the length of his drive but making up on the greens; yet still not quite resigned to the fact that his handicap has crept up from 5 to 17, while being ruefully aware of the fact that his grandson Charles can now occasionally get the better of him - on a bad day!

A.W.D. is such a constant friend, provocative critic and helpful colleague of all those who have ever worked under his influence that the idea of paying a small academic tribute to honour him seemed to arise spontaneously within this fortunate group. It is published in the Christmas number of the Journal of Hygiene, his favourite journal, on whose editorial board he served for thirty years ending only at the end of 1981. No special date is celebrated for none seems appropriate; any day this century would do! It contains papers from just a few of us as a token but carries the goodwill of those who, if listed, would cover the page.

Born 40 miles north of Aberdeen in the fishing village of Rosehearty his affection for his home ground and its sea and the sea birds remains bright and clear, yet paradoxically A.W.D. is also a cosmopolitan with a worldwide circle of friends. First among these were his early 'chiefs'; John Cruickshank in Aberdeen, Shaw Dunn and Maitland in Manchester, Prauznitz in Breslau and Sam Bedson in London. One condition of his Freedom Fellowship at the London Hospital was that he should spend eight months at the Rockefeller Institute. There in 1934/35 he worked with Avery, and formed life-long friendships with Francis, Horsfall, McLeod, Goodner, Dubos and many others. By this time he was already an outstanding bacteriologist with experience in pathology and general practice. Back at the London Hospital he extended his experience into virology by investigating the nature of vaccinia and cowpox. These early studies at the London Hospital developed into a life-long interest in poxviruses and laid the foundation for the later studies of smallpox which have made him throughout the world the best-known name in that field. But smallpox came after the war, the first four years of which he spent in charge of the Emergency P.H.L.S. Laboratory at Cambridge from whence in 1943 he went to the Chair of Bacteriology at Liverpool.

Soon after Downie's arrival in Liverpool came the end of the war and the return home by sea of large numbers of troops and the re-starting of foreign trade. This and the links with the Commonwealth made Britain the prime European focus for the importation of smallpox and Downie's combined laboratory and office on the first floor of the School of Hygiene building at the top of Mount Pleasant in Liverpool became the world centre of smallpox activity. Two gas incubators and three water baths, all controlled by Hearson's capsules; one microscope and a borrowed dental drill together with a bench centrifuge and pipettes, staining jars, pie dishes and Kahn racks and plenty of Lysol constituted the wherewithal. 
Rabbits in their cages rested on the side benches, the sheep and hens lived on the flat roof. And so it was for almost a decade until he moved down the road to an elegant new laboratory in 1954. It was in these two sites that A.W.D. ploughed a lonely furrow, for 20 years laying much of the basis of the world-wide eradication of smallpox. The old pile of visitor's photographs in the present department testifies that Liverpool became at that time the Mecca of those who wished to study the infection. They came from far and near, from both hemispheres and from either side, both of the Atlantic and of the 'iron curtain'. Downie's knowledge and experience were much in demand when the smallpox eradication campaign was being planned and at that time he spent weeks in Geneva, chairing the expert group whose technical report Smallpox Eradication was the basis for the strategy of the campaign.

Downie and Henry Kempe of Denver jointly set up a smallpox research centre in Madras from which, in collaboration with Dr A. R. Rao, a stream of research papers appeared during the 1960s. Retirement from the Liverpool chair in 1966 simply meant rejoining Henry Kempe at the Paediatric Department in Denver as visiting professor. There he ran their virus diagnostic service and held instructional courses for those who wished to learn about the laboratory diagnosis of smallpox and to play their part for W.H.O. in the field. How it was that the courteous Downie was able to run laboratory classes with smallpox crusts in Denver will probably never be known. Fortunately he is a man who knows what is needed in particular circumstances and is too astute to spend time battling with bureaucracy; also he wears a waistcoat with pockets!

The eradication of smallpox was confirmed in 1979, and we who have worked with him recognize his immense contribution. Jenner was made an F.R.S. for his study of the life history of the cuckoo. Downie, another bird watcher, was also an F.R.S. even before his studies on smallpox saw their triumph in the total eradication of that disease.

With one who remains so young the story is still incomplete and could still hold surprises for us all. But we should stop here; A.W.D. will probably recognize the encomiasts who orchestrated this piece and will be cross enough already!

\section{Editorial note}

Cambridge University Press and the editors of the Journal of Hygiene were delighted to be asked to co-operate in an academic tribute to Professor A. W. Downie. By coincidence Professor Downie and the Journal were born in the same year and some time later there was a long association between the two. More importantly, however, the aim of this issue is to pay tribute to Professor Downie's singular contribution to microbiology. One or more of the authors of each of the first twelve papers in this issue was a member of Professor Downie's department in Liverpool. Not surprisingly five of the twelve papers are concerned with various aspects of poxviruses. However, the remaining contributions are concerned with other viruses, bacteria, chlamydia and mycoplasma, indicating the diverse involvement of Professor Downie's former associates and students in current microbiology. 


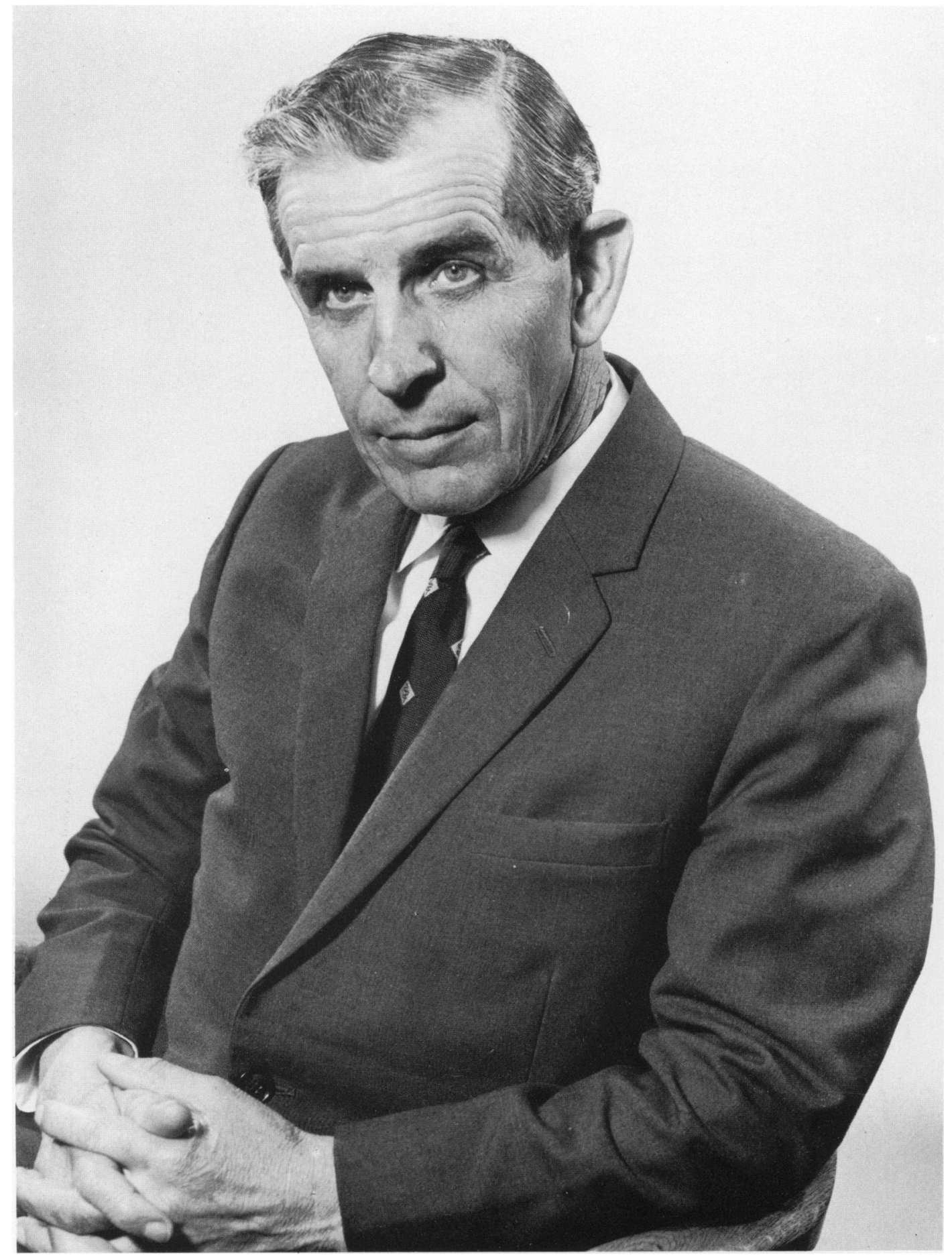

